\title{
US scientists to join Italians in dioxin study
}

An announcement is expected later this month of a joint scientific investigation into the health implications of exposure to dioxin. Alastair Hay reports on the protracted negotiations leading to this decision.

IN February the US National Academy of Sciences (NAS) will announce the formation of a binational study group to consider the public health consequences of exposure to 2,3,7,8-tetrachlorodibenzodioxin (dioxin). Behind the decision to form the group-composed of equal numbers of Italian and American scientists-lies a history of nearly two years of discussion, negotiation and some doubt as to the value of what was seen by some as nothing more than yet another committee looking into the dioxin problem.

The initiative to form the study group was taken by the NAS shortly after the accident at Sévéso in Italy in July 1976 when dioxin from a trichlorophenol reactor was discharged over a populated area. In the words of one prominent Italian scientist, the NAS wrote to the National Research Council in Italy recommending a study of Sévéso. The suggestion was couched in terms of the NAS "offering help to Italy"

It seems however, that, at that time, Italian scientists were not over-eager to conduct the study proposed by the NAS. The letter which the NAS sent went unanswered until a senior Italian scientist happened to see it by accident. Recognising its potential importance he brought it to the attention of the Minister of Health urging him to reply favourably and to invite the NAS to send a team to discuss the proposition.

The team, led by Norton Nelson. Professor of Toxicology at New York University, visited Italy in early April 1977.

When it returned, it made several recommendations including suggestions for developing a continuing relationship between US scientists and their Italian counterparts; the exchange of scientific and technical literature; the initiation of complementary research; and the organisation of workshops and exchange visits. It was suggested that the US programme be operated under a small steering group appointed by the NAS and its own National Research Council and that it relate to an 'appropriate counterpart' committee on the Italian side.

These recommendations were subsequently sent to Italy for approval together with, a request for the names of the Italian scientists who would be participating in the programme. According to the NAS the matter then 'lay dormant' until late January 1978 when a reply was received from $\mathrm{Dr}$ Pocchiari, Director of the Istituto Superiori Di Sanita in Rome, naming the Italian members and requesting the formation of the NAS counterpart committee.

It seems to have been some months before the NAS prepared its final propramme for which it sought funding The project it proposed was to be conducted in several phases, the first being simply a review of the situation. Subsequently the study groups activities might include "design and evaluation of medical follow-up studies, methods, and design of systems for emergency response to similar accidents". Thus the NAS made it quite clear that it would consider a range of issues stretching beyond Sévéso. Indeed, in its proposal the NAS Assembly of Life Sciences said that it would try to "develop guidelines and approaches to handling of future tragedies, and to the forecasting of potential environmental disasters".

Norton Nelson, who will be one of the US members of the study group, qualified the last proposal by saying that he is always wary of "cookbook recipes for accident prevention in future" and that he would be content if the joint programme merely provided some general guidelines for action.

With no funds of its own to implement the joint study programme, the NAS sought support from several other sources. According to an NAS spokesman the programme-which will last initially for two years--has been funded with some $\$ 120,000$ by the Environmental Protection Agency, National Institute for Environmental Health Sciences and the Centre for Disease Control. Asked if F. Hoffman la Roche -the parent company which owns the reactor at Sévéso-had been approached for funds as well the spokesman insisted that it had not. One of the US study group members added that Roche would be "amongst the last we would approach" for support.

The National Academy, however, did consider asking Roche for funds, early in 1978. When informed about the NAS's suggestion to approach Roche the Italian government made it quite clear that it would have no part in the study if the company played any part in funding it. Embarrassed at having considered such an approach and anxious to avoid the cancellation of its programme the NAS had to seek its finance from alternative sources.

The NAS committee members have "not yet met", according to Nelson, but will do so in early February. Following this meeting the US scientists will then meet with their Italian counterparts. "Out of that meeting we hope to formulate a programme of action", said Nelson.

Sorting out that programme could be a delicate exercise. If, as one Italian scientist put it, "it is just a NAS study in Italy, then that is very difficult and complicated. On the other hand, an international study is fine". What the Italians are looking for is a clear definition of the terms of reference of the NAS study.

One of the proposals of the NAS is that an epidemiology panel be set up. But one senior Italian scientist said that although the health surveillance programme of the Sévéso residents conducted by the Lombardy Regional Council had been less than successful he was "not sure that a new epidemiological study would work".

The protracted nature of the negotiations to establish the study group has left one of the Italian group members less than enthusiastic about the proposals, particularly as the situation at Sévéso has changed so much. One other criticism of the binational study group, advanced by some scientists, is that it is yet another committee set up to consider dioxin. Italian scientists say that the International Agency of Cancer (IARC) was to coordinate all information on dioxin yet that they have heard no more from the IARC.

Nelson denies that there will be any "duplication of effort". He says that both the IARC and World Health Organisation know about the NAS proposals and will be kept thoroughly informed.

Of one of the anxieties expressed by Italian scientists that the NAS progremme could be read as a criticism of their own activities at Sévéso, Nelson said that this should not be the case. He felt that after the two week delay in evacuating the residents of Sévéso, the authorities had acted swiftly. The NAS said Nelson had "no complaints about the handling of the situation by the Italians".

The binational study group has recently been described by one US scientist as a "committee of good intentions". Many other US scientists hope that it will be more than this and they seem relieved that the programme has actually got off the ground at last. 